Славиша Недељковић Универзитет у Нишу Филозофски факултет Департман за историју ned.slavisa@gmail.com
Оригиналан научни рад

примљено: 30. март 2014

прихваћено: 1. октобар 2014

\title{
УСТАНАК АРБАНАСА ПРОТИВ ТУРСКИХ ВЛАСТИ У СКОПСКОМ И КОСОВСКОМ ПАШАЛУКУ 1844. ГОДИНЕ (ПОБУНА ДЕРВИШ-ЦАРА)
}

Сажетак: И поред великих очекивања турских великодостојника да ће Гилхански хатишериф поправити стање набоље, догађаји који су уследили показали су супротно. Одлуке хатишерифа од Гилхане не само да нису ништа учиниле на стабилизацији економских и политичких прилика у Турској, као и на побољшању положаја хришћана, него су донеле негативне резултате. Уместо да започне период развоја и напретка Турског царства, 1839. године започео је период анархије, устанака и буна у скоро свим румелијским пашалуцима. Антиреформна пропаганда била је најјача у Старој Србији, где је тамошње арбанашко становништво заузело изразито непријатељски став према увођењу реформи. Под јаким утицајем верске идеологије, друштвено-политичка свест арбанашког становништва није трпела никакве измене у свом ставу према положају српског становништва у Турској. Незадовољство Арбанаса кулминирало је почетком 1844. године у оружаном устанку који је захватио Косовски и Скопски пашалук.

Кључне речи: Гилхански хатишериф, Стара Србија, српски народ, Османско царство, Порта, реформе, Арбанаси, побуна.

$* * *$

Од краја XVIII па до средине XIX века, Османским царством управљала су три султана-реформатора: Селим III, Махмуд II и Абдул Меџид. Реагујући на осипање моћи некадашњег великог Турског царства, они су приступили реформисању гломазне државне управе. Султани-реформатори су желели да поврате моћ Турског царства, ојачају султанову власт и спрече интервенцију европских сила у унутрашње послове турске државе. И док је султан Селим III реформом војске и финансија покушао да заустави опадање турске државе, дотле је Махмуд II отишао корак даље и извршио дубљи захват на посусталом систему традиционалног османског друштва. ${ }^{1}$ Прокламовањем Хатишерифа од Гилхане (3. новембра 1839) од

\footnotetext{
* Текст је настао као фазни резултат рада на пројекту Српска нација - интегративни и дезинтегративни процеси (број 177014) Министарства просвете, науке и технолошког развоја Републике Србије.
} 
стране султана Абдула Меџида, започео је нов политички правац у историји Османског царства познатији као танзимат и хаирлије или срећне уредбе. Овај хатишериф представљао је први акт царских власти којим је у духу западноевропских идеја проглашена равноправност за све турске поданике без обзира на њихову вероисповест. ${ }^{2}$ Гилхански хатишериф садржавао је три основна начела: неприкосновеност живота, части и имања; равноправност у начину разрезивања и сакупљања пореза и нови систем регрутације и служења војног рока. Овај хатишериф је такође предвиђао и централизацију државе и јачање власти, реорганизацију фискалног система, борбу против корупције и европеизацију судства и просвете. Ради реализације ових одлука био је основан правни Савет, који је био у обавези да донесе посебан закон како би се у што краћем року приступило спровођењу идеја заступљених у царском хатишерифу. ${ }^{3}$

Прокламовањем Хатишерифа од Гилхане, султан и Порта су желели да бар мало поправе тежак положај хришћанских поданика и да их бар формално изједначе са муслиманима, не би ли се из руку великих сила избио аргумент који би могао да им послужи за мешање у унутрашње ствари Турске. Правно, друштвено и економски ојачана на бази једнаких права и обавеза свих поданика, Турска је могла да рачуна на стабилизацију унутрашњих прилика у земљи, што би јој пред великим европским силама обезбедило даљи међународни интегритет. ${ }^{4}$ Турска царевина би на тај начин била растерећена од бројних политичких проблема који су нагризали њене темеље и могла би да започне нову епоху у историји Османског царства. Међутим, и поред великих очекивања турских великодостојника да ће Гилхански хатишериф поправити ствари набоље, догађаји који су уследили показали су супротно. Одлуке Хатишерифа од Гилхане не само да нису ништа учиниле на стабилизацији економских и политичких прилика у Турској, као и на побољшању положаја хришћана, него су донеле потпуно супротне резултате. Уместо да започне период развоја и напретка Турског царства, 1839. године започео је период анархије, устанака и буна у скоро свим румелијским пашалуцима. И поред тога што су царском прокламацијом хришћани били изједначени са муслиманима, они си и даље остали друштвена категорија другог реда под јаком доминацијом турскомуслиманских феудалаца. ${ }^{5}$ Проглашење Гилханског хатишерифа изазвало је велику озлојеђеност муслимана широм Турског царства, а нарочито у пограничним

\footnotetext{
${ }^{1}$ Васиљ Поповић, Источно питање, Београд 1996, 167; Косово и Метохија у српској историји, Београд 1989, 189-190; Стеван К. Павловић, Историја Балкана, Београд 2001, 98-101; Димитрије Ђорђевић, Националне револуиије балканских народа, Београд 1995, 43; Владимир Ћоровић, Историја Срба, Београд 1993, 584.

${ }^{2}$ Владимир Стојанчевић, Обновљена српска држава и Арбанаси 1804-1876. године, Зборник радова „Србија и Албанци у XIX и почетком XX века“, Београд 1990, 20-23; Ђорђе Микић, Друштвене и економске прилике косовских Срба у XIX и почетком XX века (од чифчијства до банкарства), Београд 1988, 86-90.

${ }^{3}$ Владимир Стојанчевић, Јужнословенски народи у Османском ияарству од Једренског мира 1829. до Париског конгреса 1856. године, Београд 1971, 145-147; Владимир Стојанчевић, Срби и Арбанаси 1804-1912, Нови Сад 1994, 73-77.

${ }^{4}$ Владимир Ћоровић, Борба за независност Балкана, Београд 1937, 78-80; Владимир Стојанчевић, Из српске националне прошлости, I, Београд 1998, 174-175; Петер Бартл, Албанщи, Београд 2001, 270-271.

${ }^{5}$ Славенко Терзић, Србија и Грчка (1856-1903), борба за Балкан, Београд 1992, 50-52.
} 
пашалуцима према Србији, Црној Гори и Аустрији. Антиреформаторска пропаганда била је веома јака и она је за увођење танзиматских реформи окривљивала искључиво хришћане. У очима муслимана хришћани су били одговорни за све проблеме у којима се налазила османска држава, те су зато они морали бити сурово кажњени. У својој искључивости према увођењу било каквих реформи које би поправиле положај хришћана нарочито се истицало арбанашко муслиманско становништво. ${ }^{6}$

Тешку политичку ситуацију у Старој Србији и Македонији додатно су погоршавале и лоше економско-социјалне прилике. Слаб принос летине и лоше саобраћајне комуникације значајно су подигли цену животних намирница, што је довело до појаве глади у старосрбијанским пашалуцима. Да зло буде још веће, због лоших хигијенских услова у појединим областима Старе Србије дошло је до појаве куге. Појаву ове опаке болести су многи сујеверни муслимани доживели као Алахову казну због одступања од шеријата и ислама и увођења безбожничких реформи. ${ }^{7}$ Све је ово распалило ратничко расположење код Арбанаса који су почели да се организују у своје племенске одреде и да прете нападом на царске паше и представнике вилајетских власти. Како је побуна скадарског Мустафа-паше Бушатлије још увек била у свежем сећању, Порта је предузела све потребне мере како би спречила понављање сличног сценарија. Према наређењу султана и Порте у правцу старосрбијанских пашалука почели су велики покрети турских трупа, чија се снага процењивала на близу 70.000 војника. ${ }^{8}$

Иако су 1840. и 1841. година наговештавале велики антиреформни покрет Арбанаса и сукобе са централним властима, до тога ипак није дошло. Разлоге за то треба тражити како у појачаном војном присуству турске војске тако и у великом устанку Срба у Нишком пашалуку који је избио априла 1841. године. Побуну хришћанског становништва муслимани у Турској одувек су сматрали за велику опасност. Чим је вест о Нишкој буни прострујала Старом Србијом, бројно арбанашко-турско становништво преко ноћи је заборавило на своје незадовољство према централним турским властима и одмах је похитало да помогне турској војсци да угуши побуну Срба. Прва половина 1842. године протекла је у појачаном присуству турске војске у Старој Србији. ${ }^{9}$ Већ од априла, пут Старе Србије кренуле

\footnotetext{
${ }^{6}$ Климент Џамбазовски, Привредне везе Бугара са Кнежевином Србијом у доба кнеза Милоша Обреновића и уставобранитеља, Београд 1986, 51-53; Јован Хаџи Васиљевић, Арнаутски покрет у XIX веку, Београд 1905, 35-36; Историја српског народа, V-I, Београд 1994, 244.

${ }^{7}$ Архив Србије (даље: АС), Министарство иностраних дела (даље: МИД), Внутрено одељење (даље: В), 1840, ф IV, p 10, № 153, Мокрогорски карантин 14. март 1840; Исто, № 204, Мокрогорски карантин 6. април 1840.

${ }^{8}$ АС, МИД, Инострано одељење (даље: И), 1840, ф IV, p 101, № 129, Рашки састанак - Попечитељству иностраних дела, Рашка 12. јуни 1840.

${ }^{9}$ Од средине XIX века назив Стара Србија јавља се све чешће у јавној употреби, не само на географским картама и у поједином списима него и у актима државне администрације Кнежевине Србије. Од тог времена започиње постепено откривање Старе Србије, пре свега у српској а затим и у међународној научној и широј јавности. Године 1852. у Новом Саду излази књига јеромонаха Гедеона Јосифа Јуришића Дечански првенац. Пишући о Старој Србији, Јуришић је напоменуо да она обухвата следеће нахије: Новопазарску, Пећку, Призренску, Ђаковачку,Скопску, Косовску, Приштинску, Вучитрнску, Врањску, Лесковачку и Нишку. Крајем 80их и почетком 90-их година XIX века учињен је одлучујући преокрет у
} 
су бројне низамске јединице, артиљерија, одреди коњаника спахија из Једрена, као и башибозлучки одреди из североисточне Македоније и западне Бугарске. Концентрацију турских трупа чија се снага процењивала на чак 80.000 људи српска влада је будно пратила. ${ }^{10}$ Нагађања на коју ће страну ударити ова турска војска трајала су до јула, када су низамске јединице и артиљерија биле послате на Крит, како би угушиле побуну Грка, док су спахије и башибозлук били послати у правцу Ниша и српске границе како би се борили против хајдучких чета, које су од пролећа 1842. године у све већем броју почеле да се јављају у северном делу Нишког пашалука.

Одлазак турске војске у правцу српске границе покушали су да искористе Арбанаси из Кумановске нахије који су поново изашли са својим старим антиреформним захтевима. Иако је у овом покрету Арбанаса учествовало око 5.000 устаника, он је трајао кратко и био је сломљен брзом интервенцијом турске војске. ${ }^{11}$ Побуна Арбанаса у Кумановској нахији била је само увертира за велики арбанашкотурски сукоб који је избио у Скопском и Косовском пашалуку почетком 1844. године у такозваној побуни Дервиш-цара. Намера турских власти да прикупи заостали порез и скупи регруте за редовну низамску војску изазвала је средином јула 1843. године снажан арбанашки отпор.

Незадовољни Арбанаси одбили су послушност царским властима и почели су да се окупљају у околини Скопља. Када је њихов број нарастао на око 3.000 бораца, Арбанаси су прекинули снабдевање града водом и блокирали су путеве који су водили у Скопље. То је изазвало брзу интервенцију Хивзи-паше који је на њих послао градски гарнизон. У ефикасној акцији турске пешадије и артиљерије, Арбанаси су били разбијени и оставили су на бојном пољу неколико десетина мртвих и рањених. Међутим, овај пораз није обесхрабрио Арбанасе, који су после само неколико дана поново почели да се окупљају на прилазима око Скопља. Окупљени Арбанаси, чија се снага процењивала на око 6.000 бораца, обавестили су турске власти да неће давати регруте за низам и да ће се оштро супротставити увођењу реформи. Претња окупљених Арбанаса да ће напасти и запалити Скопље није уплашила Хивзи-пашу, који је појачао одбрану града и од Порте затражио војну помоћ. Долазак 40 батаљона редовне војске као и војске врањског паше приморао је

\footnotetext{
поновном откривању старих средишта српског државног и духовног живота. На карти Краљевине Србије коју је Владимир Карић објавио у Београду истакнуто је да Стара Србија обухвата територију од Пљеваља и Таре до испод Скопља, што је одговарало границама ондашњег Косовског вилајета. Крајем XIX и почетком XX века повећавао се број брошура, студија и путописа о Старој Србији. Били су то радови: Стојана Новаковића, Светислава Симића, Михаила Ристића, Бранислава Нушића, Нићифора Дучића, Јована Цвијића и других. Од поменутих аутора Јован Цвијић је отишао најдаље у проучавању Старе Србије. У свом делу Основе за географију и геологију Македоније и Старе Србије, Цвијић подвлачи да се Стара Србија простире у границама тадашњег Косовског вилајета, што значи да обухвата: Рашку област, Метохију, Косово, као и Скопску, Кратовску и Тетовску област.

${ }^{10}$ АС, МИД-В, 1842, ф III, p 180, o 1341, Начелство округа Алексиначког - Попечитељству внутрених дела, Алексинац 14. јуни 1842.

${ }^{11}$ Славиша Недељковић, Србија и Косово и Метохија (1856-1897), културно-просветни и национални рад, Ниш 2012, 19; Ђоко Слијепчевић, Српско-арбанашки односи кроз векове са посебним освртом на новије време, Хилместир 1983, 147-148.
} 
Арбанасе да прекину блокаду Скопља и да се повуку у своја места. ${ }^{12}$ Арбанаси су и даље остали упорни у својим захтевима, док су њихове наоружане чете и даље биле присутне у скоро свим деловима Скопског пашалука.

Пат позиција између турских власти и Арбанаса потрајала је до почетка наредне године када је ескалирала у отворени сукоб и велики антиреформни арбанашки устанак. Арбанашка буна најпре је захватила Приштински пашалук а потом се великом брзином пренела на области Скопског, Тетовског и Врањског пашалука. Побуна незадовољних Арбанаса почела је силовито. На самом почетку устанка побуњеници су успели да потисну слабе гарнизоне турске војске и да загосподаре Лесковачком, Врањском, Прокупачком, Куршумлијском, Приштинском, Гњиланском, Скопском, Кумановском, Дебарском, Тетовском и Гостиварском нахијом. ${ }^{13}$ Устаници су под своју власт успели да ставе административне центре као што су били: Лесковац, Врање, Приштина, Скопље, Тетово, Велес и Прилеп, док су Битољ држали у блокади. ${ }^{14}$

У побуњеним крајевима, институције турских власти биле су укинуте. Локални управитељи и чиновници били су протерани или су сами побегли испред наоружаних одреда побуњеника. Једна од првих вароши која је дошла под удар Арбанаса било је Врање. Арбанашка војска у јачини од 15.000 људи напала је ову варош, сломила слаб отпор тамошњег гарнизона и насилно протерала врањског Хусни-пашу. По заузећу вароши, Арбанаси су разграбили и опљачкали сву имовину Хусни-паше а потом су запалили његов конак. Бежећи од Арбанаса, Хусни-паша је отишао у Битољ, где је потражио помоћ од великог везира који је у то време преговарао са побуњеним арбанашким старешинама. ${ }^{15}$ Преговори су трајали неколико дана и нису донели никакве резултате, јер су Арбанаси упорно инсистирали на томе да неће давати регруте за низам, и да ни по коју цену неће прихватити танзиматске реформе. Судбина врањског Хусни-паше снашла је и приштинског Абдурахман-пашу, као и Дели-бега из Тетова. Приштински Абдурахман-паша морао је да се склони у Призрен, одакле је више пута безуспешно покушавао да се уз помоћ призренског паше који је командовао војском од 6.000 људи врати у Приштину. Слично је било и са тетовским господаром Дели-бегом, који је пред арбанашким четама морао да се склони код дебарског господара Хаџипаше. ${ }^{16}$ После заузимања Врања, арбанашка војска у јачини од око 12.000 бораца отишла је ка Лесковцу, где је на Емир-пољу, у непосредној близини ове вароши, подигла војни логор. Окупљеним Арбанасима који су очекивали резултате преговора у Битољу стално су се прикључивале нове чете, тако да је за кратко време њихов

\footnotetext{
${ }^{12}$ АС, МИД-И, 1843, ф III, p 9, о 909, Окружни начелник Алексиначког округа потпуковник Ћирковић Попечитељству иностраних дела, Алексинац 5. јули 1843.

${ }^{13}$ АС, МИД-В, 1844, ф II, р 221, К в. № 499, Карантин Алексиначки - Попечитељству внутрених дела, Алексинац 10. април 1844; Грађа за историју македонског народа из Архива Србије, приредио Климент Џамбазовски, том I, књига I, (1820-1848), Београд 1979, 303-304.

${ }^{14}$ Косово некад и сад, Београд 1973, 153.

15 АС, МИД-В, 1844, ф II, р 221, К в № 499, Карантин Алексиначки - Попечитељтву внутрених дела, Алексинац 10. април 1844.

${ }^{16}$ Владимир Стојанчевић, Јужнословенски народи у Османском ияарству од Једренског мира 1829. до Париског конгреса 1856, 230.
} 
број нарастао на око 30.000 људи. ${ }^{17}$

Истовремено са нападима на Врање и Лесковац, један део арбанашке војске кренуо је ка Прокупљу и Нишу. Концентрација арбанашких чета у околини Ниша приморала је команданта градског гарнизона Ђејнал-агу да подигне степен борбене готовости и постави јаке страже на свим прилазима Нишу. Поред тога, пешадијске чете ојачане артиљеријом запоселе су све мостове преко Мораве, док су све скеле ради сигурности биле извучене на суво. ${ }^{18}$ Немирно је било и у Скопском пашалуку где су Арбанаси блокирали саобраћајнице и порушили мостове на потезу између Велеса и Скопља. ${ }^{19}$ Побуњени Арбанаси заузели су Скопље и од Порте су затражили да смени Хивзи-пашу. ${ }^{20}$ Центар арбанашког отпора био је у селу Катланово у коме се налазило око 8.000 устаника. Из овог места кретали су бројни напади на представнике турске власти широм Скопског пашалука. ${ }^{21}$

На челу побуњених Арбанаса налазио се Дервиш, арбанашки старешина из села Џаре из Тетовске нахије. ${ }^{22}$ Поред њега значајну улогу у овом устанку имале су и арбанашке старешине Сеиди Менџе и Баба Феке. Сеиди је припадао арбанашком братству Менџе које је имало поседе у Гргуру и Топлици, као и мало земље у околини Крушевца. ${ }^{23}$ Иако су поседовали значајне читлуке, припадници овог братства често су нападали и пљачкали не само Србе већ и Турке. Тако је почетком 1824. године из освете убијен Хусеин, стриц Сејди Менџеа, који је са својом четом, правио велике проблеме крушевачким Турцима. ${ }^{24}$ Када је 1821. године почео устанак хетериста у Грчкој, Сеиди Менџе се као правоверни муслиман одазвао позиву на џихад, те је као предводник башибозлучке јединице учествовао у борбама у северној Грчкој. Сеиди Менџе се посебно истакао у борбама око Ларисе које су вођене у лето 1822. године. ${ }^{25}$ Због тога га је Порта наградила тако што га је поставила за крушевачког забита. ${ }^{26}$

Када је у пролеће 1841. године избио устанак Срба у Нишком пашалуку, Сејди Менџе се са својим Арбанасима одмах укључио у борбу против српских устаника. По сламању Нишке буне он је предводио чету од 250 људи која је у црно завила многа српска села. ${ }^{27}$ Поред Сеиди Менџеа, велику улогу у вођењу арбанашке

\footnotetext{
${ }_{17}^{17}$ Грађа за историју македонског народа из Архива Србије, 301-303.

${ }^{18}$ АС, МИД-И, 1844, ф I, р 121, о 340, Начелство Алексиначког округа-Попечитељству иностраних дела, 13. март 1844.

${ }^{19}$ Грађа за историју македонског народа из Архива Србије, 307.

${ }^{20}$ Јован Хаџи Васиљевић, Скопље и његова околина, Београд 1930, 79.

${ }^{21}$ АС, МИД-В, 1844, ф II, р 221, С № 361, Карантин Алексиначки - Попечитељству внутрених дела, Алексинац 13. април 1844.

${ }^{22}$ Ђ. Слијепчевић, Нав. дело, 147.

${ }^{23}$ АС, МИД-В, 1844, ф II, p 221, К в № 501, Начелство округа Крушевачког - Попечитељству внутрених дела, Крушевац 13. април 1844.

${ }^{24}$ АС, Књажева канцеларија (даље: КК), 1824, ХІІ, 348, Живко Шкорић - Кнезу Милошу Обреновићу, Вукомановци 8. март 1824.

${ }^{25}$ Исто, 1822, ХII, 190, Јанићије Радовић - Кнезу Милошу Обреновићу, Јагодина 10. август 1822.

${ }^{26}$ АС, МИД-В, ф III, p 151, № 2308, Главни секретар Совјета мајор Стефан Марковић - Вицепредседнику Совјета Стојану Симићу, Београд 21. децембар 1839.

${ }^{27}$ Славиша Недељковић, Учешће Арбанаса у гушењу Нишке буне 1841. године, Зборник радова са научног скупа „Устанци и побуне Срба у Турској у XIX веку (поводом 170. година од избијања Нишке буне)“, Ниш 2012, 22-23.
} 
побуне имао је и Баба Феке. И он је, као и Сеиди Менџе, био познат као предводник башибозлука и велики зулумћар над хришћанском рајом. Како је био у поодмаклој старости, није директно учествовао у борбама, већ је помагао Дервиш-цару у организовању арбанашког устанка. ${ }^{28}$

Антиреформни устанак Арбанаса из 1844. године био је добрим делом уперен против хришћанске раје. Стара верска мржња према хришћанима ескалирала је већ у првим данима арбанашке побуне. Један од разлога због којих су Арбанаси напали Врање био је подизање српске цркве у тој вароши. Чим су Арбанаси заузели Врање, одмах су почели да пљачкају и убијају српске трговце и занатлије. Арбанаси су опустошили и бројна српска села између Врања и Лесковца чинећи притом злочине најгоре врсте. ${ }^{29}$ Слична ситуација била је и у Скопском пашалуку. На удару арбанашких чета нарочито су се нашла српска села у Скопској Црној Гори „на које су Арбанаси порез разрезали и рабош ${ }^{30}$ им дали, и запретили су Србима да ће их побити и села им запалити уколико не учине оно што им се заповеда и не дају им рабош“."31 Зулуми који су за време побуне Дервиш-цара вршени над српским становништвом по окрутности су прелазили уобичајне норме мучења и понижавања хришћанске раје. Тако су у селу Јенцикову, да би изнудили новац од мештана, Арбанаси најпре мучили а потом живе спалили једну жену са два детета. Слично се десило и у селу Белибегово где је на монструозан начин убијен српски трговац Павковић са своја два сина. ${ }^{32}$

И поред тога што је арбанашки антиреформни устанак из 1844. године био динамичан и обухватао велику територију, трајао релативно кратко. Разлог за то налазио се у брзој и ефикасној интервенцији централних турских власти, које нису желеле понављање сценарија из Бушатлијине и Градашчевићеве побуне. Порта није хтела да дозволи да се овај устанак прошири и на остале пашалуке у Румелији па је већ у априлу почела концентрацију трупа у пашалуцима који су се граничили са побуњеним областима. Тако је већ средином месеца, из Битоља у Велес, било послато 20 батаљона редовне војске са артиљеријом. За сераскера ове војске постављен је Хусеин-паша из Врања, кога су неколико недеља раније Арбанаси протерали из овог града. ${ }^{33}$

У исто време, Порта је у предстојећим војним припремама ангажовала и протераног тетовског господара Дели-бега. Њему су централне власти обећале да ће, уколико буде помогао да се сломи побуна Дервиш-цара, бити постављен за пашу и

\footnotetext{
${ }^{28}$ АС, МИД-В, 1844, ф II, р 221, К в № 501, Начелство округа Крушевачког - Попечитељству внутрених дела, Крушевац 13. април 1844.

${ }^{29}$ Исто, 6. април 1844; Исто, ф I, р 24, П о 839, Попечитељство внутрених дела - Државном савету, Београд 10. април 1844.

${ }^{30}$ Рабош - дрвени штапић на коме су урезиване рецке. Рабошем су Арбанаси уцењивали и глобили Србе у Старој Србији. Број рецки означавао је суму новца (обично златне турске лире), коју је неки домаћин Србин морао да исплати неком арбанашком разбојнику који му је послао рабош.

${ }_{31}$ АС, МИД-В, 1844, ф II, р 221, № 399, Начелство Алексиначког округа - Попечитељству внутрених дела, Алексинац 24. април 1844.

32 АС, МИД-И, 1844, ф III, р 6, № 230, Алексиначки карантин - Попечитељству иностраних дела, Алексинац 6. март 1844.

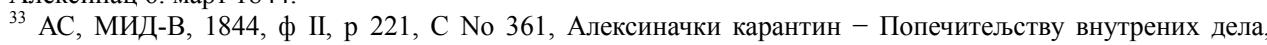
Алексинац 13. април 1844.
} 
да ће на управљање добити Тетовску, Гостиварску и Кичевску област. Дели-бег је ову понуду оберучке прихватио, тако да је одмах почео да прикупља људство и да за предстојећи војни поход складишти храну, муницију и остали војни материјал. ${ }^{34}$ Овај потез централних власти показао се као веома добар, тако да су у предстојећој војној кампањи против побуњених Арбанаса Хусеин-паша и Дели-бег имали веома запажену улогу. ${ }^{35}$ Пошто је извршила концентрацију трупа, Порта је у другој половини маја покренула офанзиву на побуњене Арбанасе. У правцу Дервиш-цара и његових Арбанаса, кретала се значајна турска војна сила. Румелијска војска имала је главни задатак у војној кампањи, и њу су сачињавале снаге од 10.000 војника које је предводио румелијски сераскер Решид-паша и одред од 5.000 низама којима је командовао Хајрудин-паша. ${ }^{36}$ Уз одреде румелијске војске, марширали су и помоћни одреди Тоски у јачини од око 3.000 људи, којима су командовали Дели-бег тетовски и дебарски забит Шаин-бег. Истовремено са покретима румелијске војске, у правцу Нишког и Лесковачког пашалука кренули су и јаки одреди низама из западне Бугарске. ${ }^{37}$

Главни судар Арбанаса и турске војске десио се код села Катланова у близини Скопља. Царска војска у јачини од 6.000 људи, којом је командовао најбољи турски румелијски официр Омер-паша, сукобила се са око 8.000 побуњених Арбанаса. У жестоком судару Арбанаси су били потпуно разбијени, остављајући на

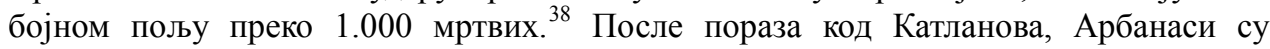
концентрисали своје снаге у Качанику одакле су намеравали да пруже отпор турској војсци и зауставе њено даље напредовање. Међутим, упркос очекивањима арбанашких старешина, у следећем сукобу који се јуна 1844. године водио на прилазима Качанику поново су победиле царске трупе. ${ }^{39}$ Убрзо по сламању арбанашког отпора код Качаника, румелијски сераскер Решид-паша и Омер-паша ушли су у Скопље, где су поставили свој војни штаб. Одмах по уласку у Скопље, турска војска је почела да хапси устаничке старешине тако да је за кратко време било ухваћено око 200 Арбанаса који су послати за Цариград. У исто време, одреди којима је командовао Дели-бег успели су да разбију устаничке чете у Тетовској нахији и да потом, готово без борбе, уђу у Тетово. ${ }^{40}$ Турска победа код Качаника означила је слом устанка Дервиш-цара. Увидевши да испред себе имају праву војску,

\footnotetext{
${ }^{34}$ Грађа за историју македонског народа из Архива Србије, 303-304.

35 АС, МИД-В, 1844, ф II, р 221, С № 883, Попечитељ внутрених дела, пуковник кавалир Илија М. Гарашанин - Српском кнезу Александру Карађорђевићу, Београд 16. мај 1844.

${ }_{36}$ В. Стојанчевић, Јужнословенски народи у Османском ичарству од Једренског мира 1829. до Париског конгреса 1856. године, 230-231.

${ }^{37}$ АС, МИД-В, 1844, ф II, р 221, П о 2653, Попечитељ внутрених дела, пуковник кавалир Илија М. Гарашанин - Српском кнезу Александру Карађорђевићу, Београд 13. јуни 1844; Исто, С № 883 , Попечитељ внутрених дела, пуковник кавалир Илија М. Гарашанин - Српском кнезу Александру Карађорђевићу, Београд 16. мај 1844.

${ }^{38}$ В. Стојанчевић, Јужнословенски народи у Османском ияарству од Једренског мира 1829. до Париског конгреса 1856. године, 230; Косово некад и сад, 153.

39 АС, МИД-В, 1844, ф II, р 221, П о 237, Попечитељ внутрених дела, пуковник кавалир Илија М. Гарашанин - Српском кнезу Александру Карађорђевићу, Београд 1. јуни 1844.

40 В. Стојанчевић, Јужнословенски народи у Османском ияарству од Једренског мира 1829. до Париског конгреса 1856. године, 230.
} 
а не племенску полувојну формацију, Арбанаси су се масовно предавали турској војсци тражећи амнестију, молећи притом турске војне команданте да војска не залази дубље у њихове области и не уништава њихова села. ${ }^{41}$

Добивши потребна појачања, турска војска је кренула у коначан обрачун са побуњеницима. Према српским обавештајним подацима у ову акцију је било укључено око 50.000 турских војника. Од тога је 20.000 војника кренуло на Косово, док је 30.000 низама остало у Скопском пашалуку. ${ }^{42}$ Убрзо по заузимању Скопља, турска војска је ушла у Врање, Призрен, Ђаковицу и Пећ, разоружавајући успут Арбанасе и хватајући њихове старешине. Вођа арбанашког устанка Дервиш-цар био је ухваћен и са око триста арбанашких стрешина везаних руку и ногу на коњским самарима послат је у Цариград. ${ }^{43}$ У жељи да бар мало смањи своју одговорност за све оно што се протеклих месеци дешавало на простору Старе Србије, Дервиш-цар је одмах по хапшењу изјавио да су главни иницијатори арбанашке побуне били видински Хусеин-паша, нишки Ђениђи-ага и лесковачки Исмаил-паша и „да је он све што је чинио, чинио искључиво по њиховом налогу“. Дервиш-цар је, како су и сами турски официри приметили, показао велик степен сарадње са иследним органима и није био ни налик осионом и суровом арбанашком господару који је српском становништву у Старој Србији задавао велику муку и јад. Иако речима Дервиш-цара није био придаван велики значај, традиционално сумњичава Порта је одмах по депортацији арбанашких побуњеника у Цариград са положаја уклонила лесковачког пашу и прокупачког забита и послала их у Једрене. ${ }^{44}$

После хватања Дервиш-цара, јаки одреди турске војске улогорили су се код манастира Дечани и у акцијама спроведеним у Пећкој и Ђаковачкој нахији похватали још двеста Арбанаса, које су везане послали за Скопље. Турске трупе су по наређењу Порте улазиле у арбанашка села, разоружавале Арбанасе и истовремено стављале под заштиту српску хришћанску рају. На подручју Скопског, Тетовског и Приштинског пашалука завладао је мир а јавна безбедност и сигурност поново су успостављене. ${ }^{45}$ Како су, упркос бројним потерама турске војске, Сејди Менџе и Баба Феке још увек били на слободи, Порта је средином септембра наредила приштинском Јашар-паши и команданту нишког гарнизона да у садејству са трупама које су пристигле из Скопља и Цариграда „под опсаду ставе Топличку и Куршумлијску нахију и похватају преостале бегунце“. ${ }^{46}$ Почетком октобра Сејди Менџе је са неколико својих људи био ухваћен и у оковима послат у Цариград, док

41 АС, МИД-И, 1844, ф ІІІ, р 6, о 1343, Начелник Крушевачког округа Радован Петровић Попечитељству иностраних дела, Крушевац 5. јуни 1844; Исто, № 1660, Начелник Крушевачког округа Радован Петровић - Попечитељству иностраних дела, Крушевац 5. јули 1844.

${ }^{42}$ Исто, 1844, ф III, p 6, No 1346, Начелник Ужичког округа Милојица Трифуновић - Попечитељству иностраних дела, Ужице 5. јули 1844.

${ }^{43}$ Исто, № 1660, Начелник Крушевачког округа Радован Петровић - Попечитељству иностраних дела, Ужице 5. јули 1844

${ }_{44}^{44}$ Исто, № 1343, Начелник Крушевачког округа Радован Петровић - Попечитељству иностраних дела, Крушевац 5. јуни 1844.

${ }^{45}$ В. Стојанчевић, Јужнословенски народи у Османском ияарству од Једренског мира 1829. до Париског конгреса 1856. године, 231.

${ }^{46}$ АС, МИД-И, 1844, ф III, р 6, о 2506, Начелник Крушевачког округа мајор Радован Петровић Попечитељству иностраних дела, Крушевац 25. септембар 1844. 
се Баба Феке неко време крио у близини српске границе а потом је и он доживео судбину својих сабораца. Желећи да додатно казни ове арбанашке старешине, турска војска им је конфисковала сву покретну имовину, спалила домове и раселила породице. $^{47}$

После сламања арбанашке антиреформне побуне, Порта је кренула са спровођењем реформи и реорганизацијом локалних органа власти у свим пашалуцима на простору Старе Србије. По наређењу централних власти, румеливалија Решид-паша је за команданта Скопског пашалука поставио свог ћехају Ћор Мехмед-пашу, док је на његово место поставио Хајрудин-пашу. После сређивања прилика у косовско-метохијским пашалуцима румелијски сераскер, валија Решидпаша, отишао је у Тетово, док је Хајрудин-паша отишао у Дебар. Након сређивања прилика и у овим областима, Порта је почела са формирањем редифских ${ }^{48}$ батаљона, који су као резервне формације турске војске могли да се по потреби упуте и у остале делове царства. Ове мобилне резервне формације биле су формиране од Арбанаса из Скопља, Тетова, Дебра, Приштине, Призрена, Пећи и Ђаковице. Докраја новембра, Порта је за потребе редифа, из ових крајева, регрутовала неколико хиљада људи. Успешно спровођење регрутације као и осталих реформних мера обезбеђивале су јаке јединице турске војске које су биле стациониране у Скопљу, Тетову, Велесу, Охриду, Битољу, Приштини и Призрену. ${ }^{49}$

Сламањем побуне Дервиш-цара Турска је показала да још увек поседује значајну војну силу са којом лако може да изађе на крај са оружаним побунама на својој територији. Међутим, турским властима није ишло у интерес даље заоштравање односа са арбанашким становништвом. Због тога је Порта врло брзо по сламању побуне Дервиш-цара показала велику заинтересованост да што пре „заборави“ своје сукобе са Арбанасима. Желећи да у најкраћем року нормализује своје односе са Арбанасима, Порта је амнестирала побуњенике тако да су се многи после само шест месеци, а преостали после годину дана, вратили у своја родна места чинећи још веће зулуме над незаштићеним српским становништвом. ${ }^{50}$

\footnotetext{
${ }^{47}$ Исто, № 2648, Начелник Крушевачког округа мајор Радован Петровић - Попечитељству иностраних дела, Крушевац 9. октобар 1844.

48 Турска војска била је подељена на низам - активну војску са роком служења од пет година, и на редиф - резервне снаге са војним роком служења од седам година.

${ }_{49}$ В. Стојанчевић, Јужнословенски народи у Османском ицарству од Једренског мира 1829. до Париског конгреса 1856. године, 231.

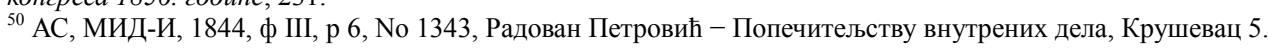
јули 1844.
} 


\section{Извори и литература:}

Извори и грађа:

Архив Србије

Министарство иностраних дела, Внутрено одељење.

Министарство иностраних дела, Инострано одељење.

Књажева канцеларија.

Грађа за историју македонског народа из Архива Србије, приредио Климент Џамбазовски, том I, књига I (1820-1848), Београд 1979.

\section{Литература:}

Бартл, Петер, Албанщи, Београд 2001.

Васиљевић, Хаџи Јован, Арнаутски покрет у ХIX веку, Београд 1905.

Васиљевић, Хаџи Јован, Скопље и његова околина, Београд 1930.

Ђорђевић, Димитрије, Националне револуиије балканских народа, Београд 1995.

Историја српског народа, књ. V-1, Београд 1994.

Косово некад и сад, (група аутора), Београд 1973.

Косово и Метохија у српској историји, (група аутора), Београд 1989.

Микић, Ђорђе, Друштвене и економске прилике косовских Срба у ХІХ и почетком ХХ века (од чифчијства до банкарства), Београд 1988.

Недељковић, Славиша, Србија и Косово и Метохија (1856-1897), културно-просветни и начионални рад, Ниш 2012.

Недељковић, Славиша, Учешће Арбанаса у гушену Нишке буне 1841. године, Зборник радова „Устанци и побуне Срба у Турској у ХIX веку (поводом 170. година од избијања Нишке буне)“, Ниш 2012.

Павловић, Стеван К., Историја Балкана, Београд 2001.

Поповић, Васиљ, Источно питање, Београд 1996.

Слијепчевић, Ђоко, Српско-арбанашки односи кроз векове са посебним освртом на новије време, Хилместир 1983.

Стојанчевић, Владимир, Јужнословенски народи у Османском иарству од Једренског мира 1829. до Париског конгреса 1856. године, Београд 1971.

Стојанчевић, Владимир, Обновљена српска држава и Арбанаси 1804-1876. године, Зборник радова „Србија и Албанци у ХІХ и почетком XX века, Београд 1990.

Стојанчевић, Владимир, Срби и Арбанаси 1804-1912, Нови Сад 1994.

Стојанчевић, Владимир, Из српске начионалне прошлости, I, Београд 1998.

Терзић, Славенко, Србија и Грчка (1856-1903), борба за Балкан, Београд 1992.

Ћоровић, Владимир, Борба за независност Балкана, Београд 1937.

Ћоровић, Владимир, Историја Срба, Београд 1993.

Џамбазовски, Климент, Привредне везе Бугара са Кнежевином Србијом у доба Кнеза Милоша Обреновића и уставобранитеља, Београд 1986. 


\title{
THE UPRISING OF THE ARNAUTS AGAINST THE TURKISH AUTHORITIES IN PASHALIK OF SKOPJE AND KOSOVO IN 1844 (REBELLION OF THE DERVISH EMPEROR)
}

\begin{abstract}
Summary
Despite high expectations of central Turkish authorities that the proclamation of the Hatt-1 Şerif of Gülhane would re-establish order in the Ottoman Empire, the events that followed proved otherwise. Decisions of the Hatt-1 Şerif of Gülhane not only did nothing to stabilise the political and economic situation in Turkey and improve the status of Christians, but actually had negative results. Instead of a period of progress and development in the Ottoman Empire, in 1839 began a period of anarchy, rebellions and uprisings in almost all pashaliks of Rumelia vilayet. The main category which defined the social and agrarian legal relations was faith. Religious teachings of Islam and Sharia Law clearly defined the position of the non-Muslim population as second-class citizens, who did not have the right to influence the social, political and economic conditions in the Ottoman Empire. Anti-reform propaganda was strongest in Old Serbia, where the local population of Arnauts took extremely hostile stance on the introduced reforms. Heavily influenced by their religious ideology, socio-politically conscious Arnauts did not change their attitude towards the position of Serbian population in Turkey. Dissatisfaction of Arnauts culminated in 1844 in the uprising that spread to Pashaliks of Kosovo and Skopje.
\end{abstract}

Keywords: The Hatt-1 Şerif of Gülhane, Old Serbia, Serbian people, Ottoman Empire, the Porte, reforms, Arnauts, rebellion. 